\title{
Women Participation in Flood Risk Management: A Case Study in Char South Baladoba in Kurigram District
}

\author{
A. T. M. Zinnatul Bassar, Anjum Tasnuva \\ Department of Disaster Management, Begum Rokeya University, Rangpur, Bangladesh
}

Email address:

bassar@brur.ac.bd (A. T. M. Z. Bassar),keka_es_ku@yahoo.com (A. Tasnuva)

\section{To cite this article:}

A. T. M. Zinnatul Bassar, Anjum Tasnuva. Women Participation in Flood Risk Management: A Case Study in Char South Baladoba in Kurigram District. American Journal of Environmental Protection. Vol. 6, No. 1, 2017, pp. 7-17. doi: 10.11648/j.ajep.20170601.12

Received: January 5, 2017; Accepted: January 14, 2017; Published: February 10, 2017

\begin{abstract}
The study in char Baladoba of Begumgonj union of Kurigram district describes participation and role of women in the manipulation of a common disaster flood. By synthesizing the division of labor, it is seen that female members play a significant role compared to male members of the community, especially from the preparedness for flood disaster to response and tasks of post disasters as rehabilitation, reconstruction, restoration etc. Using a recent survey in this region, the paper finds that women have a positive role on mitigating seasonal deprivation although they can keep minor role decision making process. The results are robust. Although division of labor shows that women keep role in maximum effort, finally it is seen that the status of women and their importance to play role in decision making are ignored.
\end{abstract}

Keywords: Flood, Women, Preparedness, Char

\section{Introduction}

Bangladesh faces natural disasters almost surrounding the year. Due to its weather system, Bangladesh is the worst victimized country of natural disasters which causes loss of lives and properties [1]. People, mainly those in the riverside, low-lying and coastal areas endure harsh natural calamities similar to floods, cyclones, heavy storms, river erosions, excessive rains etc. within these flood is the most common fact in our country. Floods alone cause enormous remains to the standing crops, livestock, houses and other assets, communication services, and whirling thousands of people homeless. When natural disasters and environmental change occur, women and men are affected differently because of traditional, socially-based roles and responsibilities [2]. Women suffer climate impacts more than men and are also integral to solutions [3]. Despite the pivotal role in household management, their due participation in decision and policymaking and development process is still undermined [4] In the aspect of social structure in Bangladesh women's status and position is inferior. Although their subordinate state in the society and inequity against them, women have certain capability that facilitate not only women but the full family to cope well during disaster. Daily domestic tasks, child rearing and services to rest of the members in the household are apparent as the main role of women. Flood creates intolerable communal crisis and stress for women. Casually women are the most awful victims of natural and human induced disasters compared to men. Women's liability and workload expand in diverse way during disaster. Women bring unique experiences and valuable skills that would benefit disaster risk mitigation and preparedness [5]. Women perform a long range of activities in order to cope and adapt with a climate change induced and other forms of disasters [6]. Women draw upon their own store; procure food and process; draw upon own assets; adjust their own consumption pattern; draw upon aquatic food; draw upon social network [6].

Disasters can demolish the environment, but the women have to still carry out their habitual responsibilities similar to preparation of food, collection of fuel and water, often under unfeasible situation. The physical burden of coping falls heavily on women. They have to survive by adopting strategies to cope up with all odds of nature and the society [7]. Fulfillment of women's traditional role to meet the immediate survival needs of their households becomes more difficult during flood situation. Earning of the affected families is reduced. In that period they do not have foodstuff or arrangements for cooking food. They cannot survive in their dwelling because of inundation. Women have to go to a long distance to fetch potable water. In addition to the obligation 
outside the household they are to look after family members. Especially ensuring cooked meals and drinking water every day for everybody remains on women. For the poor women-headed households the situation even gets more difficult. These unpaid work carried out by both men and women for community benefit could be divided into two; community managing for which women are mostly exploited to obtain their free service while men play community politics by keeping the decision making power which brings status to themselves [8].

Women have to take considerable risks to procure drinking water from long distance by boat or raft. When there is nothing to eat it is the mother who practically looks for a way to feed the children and has to invent the last survival maneuvers [9]. In the poorer households, women are commonly seen to sacrifice their own meals for their husbands and children. When women are completely helpless without any source of income and shelter they usually move out to non affected areas. However, this migration does not make their lives easier [10].

Climate change will contribute to increased frequency and severity of disasters with adverse impacts on human life. Although disasters and climate change affect all segments of the population, there are gender variations to vulnerability, capability and resilience. The impacts of climate change and disasters are differentiated for women and men. Climate change impacts are also far more severe for women, the poor and marginalized groups because of societal inequality such as unequal power, lack of information and lack of decision making ability [11],[12]. Women also lack access to productive resources, in particular land. Often more women than men are affected in their multiple roles as food producers and providers as guardians of health, caregivers to the family and community and as economic actors [6]. As access to basic assets and natural resources, such as shelter, food, fertile land, water and fuel becomes hampered, particularly women's workload increases. Lack of natural resources, caused by flooding, drought and erratic rainfall cause women to work harder to secure natural resources and livelihoods [6].

Women's vulnerability is different from men that have increased throughout the socialization practice. Women are more susceptible to disasters not for the reason that they are physically weak, but they face diverse conditionality in the societies conducted by superstitious traditions. Generally, in many developing countries women often live in conditions of social exclusion, such as cultural limitations to mobilize outside their immediate environment; have less access to information to early warning systems in times of disasters, and to forecasts of climate variability; and have difficulties in participating in training processes [13]. Women, usually, are liable for reproductive responsibilities such as several care-giving tasks, concerning for the kids, ill and elderly and the livestock, home and assets. In the time of disaster primarily socio- cultural rules and care giving tasks prevent women from migrating to look for shelter and work. In case of many disasters drinking water, sanitation and health challenges put more load on women. The gendered division of labor becomes critical as gender roles are often re- enforced and even intensified for the additional work and changes in environment brought on by a disaster. Violation of women's rights becomes more prominent during a disaster [14].

Women undertake preparedness measures based on their realistic experiences. Such as Mobile Chula, storing dry food like chira, muri, dry fish etc., fuel for cooking, preserving fodder and poultry feed and creating chhika. During flood period women, in addition to their daily usual activities, obtain a principal part in taking care of children, sick and elderly people as well as livestock. They also provide mental support to the family members and making initiatives for collecting relief materials, food and fuel. Generally, women hardly ever obtain any recognition for such role.

\section{Methodology}

This research provides an overview of the two research methods utilized to conduct this study, qualitative and quantitative method. Quantitative data have been collected through questionnaire survey and qualitative data have been gathered through case studies, key informants interview and focus group discussion. Researchers observation is also included as part of qualitative method.

\subsection{Study Site}

An exploratory inventory was conducted continuously at south Baladoba char in Begumganj union in Kurigram district of Rangpur division in April, 2015 to explore information regarding women participation in disaster risk reduction.

This study utilized purposive/judgmental sampling, a non probability sampling technique. The sample was preselected according to expert opinion about which subjects were the most useful and representative of those who are living in the char. Char south Baladoba was purposively selected from Begumganj union of Kurigram district of Rangpur division. Households from the char were randomly selected from the char.

\subsection{Sources of Data}

The data for this study were collected basically from two sources:

a) Primary and

b) Secondary sources

a) The primary data were collected from people of south baladoba char. The data collected from men and women provided the information about the actual situation of the char area.

A questionnaire survey was conducted randomly in 100 households in the charland. Ten focus group discussions were done in which 10 to 18 participants were present in each focus group. Five case studies were conducted to gather proper information from the households.

b) Secondary data:

Secondary resources were mainly used to understand the concept of policy implementation by analyzing definitions offered by various scholars. Moreover the literature reviewed facilitated in chalking out the theoretical framework for the study. 

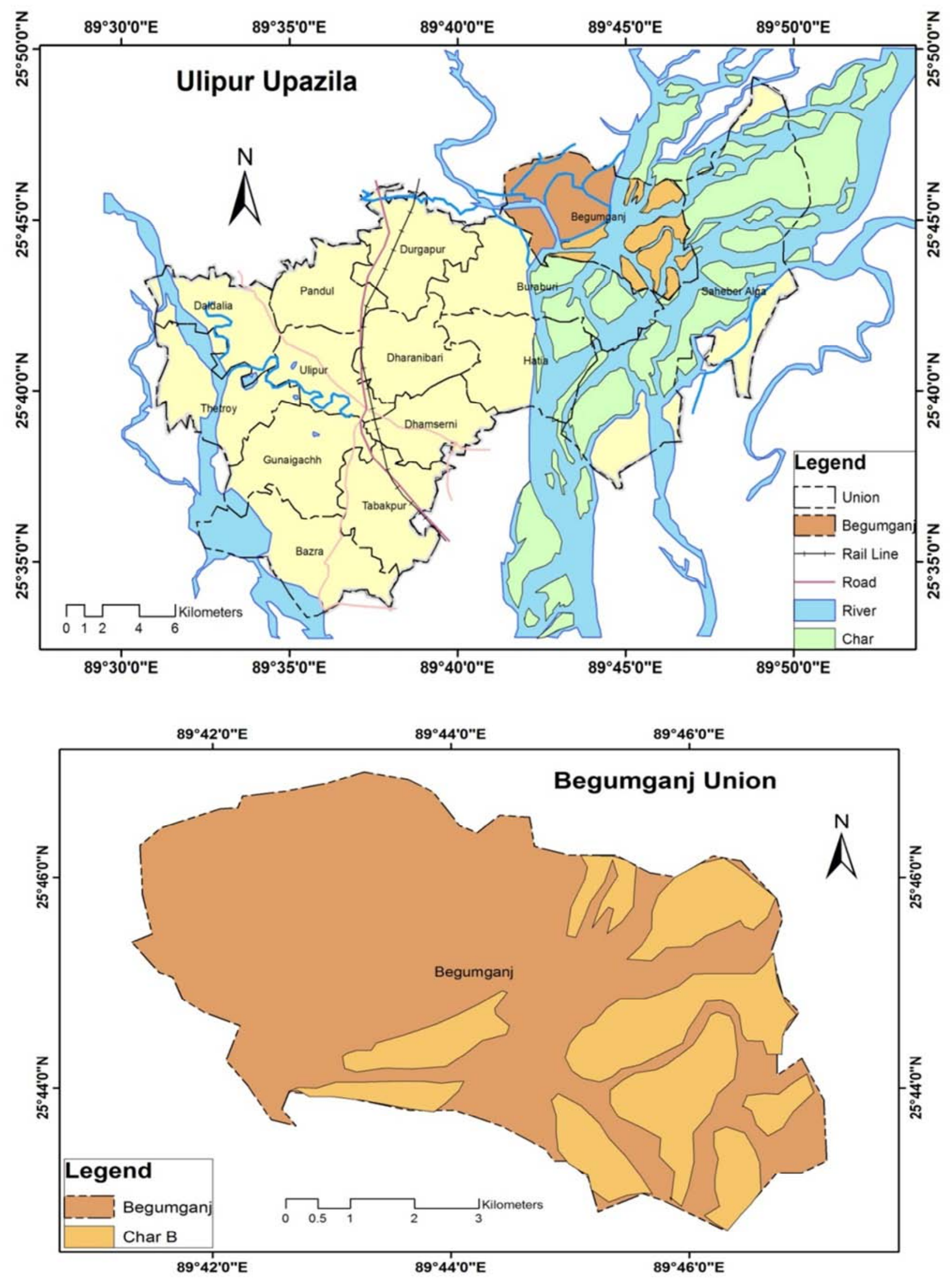

Figure 1. Char Area of Begumgonj Union of Ulipur Upazilla of Kurigram. 


\subsection{Data Collection Process}

The field observation was done to see the existing situation and cross check the people opinion with real field. This was done in transect of the study areas. A questionnaire survey which includes different types of information about the respondents (name, sex, occupation etc.), structure of sample households, their livelihood patterns was followed.

The first method used in this research was that of survey with quantitative data and qualitative interviews, an ideal method for testing the existing role of women in disaster risk reduction. As this research was exploratory, qualitative interviews were an appropriate method as they allowed the interviewer to establish a general direction for the conversation and gave freedom to pursue topics raised by the respondents. Qualitative interviews not only provided information relevant to the targeted objective but also led to the discovery of additional elements those were useful to relate the theoretical framework for long term disaster recovery programs.
The data were obtained through informal discussions which include conversation with the local people in a hilarious manner as gossiping, ten focus group discussions, five case studies with the local people and finally the data were cross checked through key informants interview in which chairman of the upazilla was included.

\section{Result and Discussion}

\subsection{Socio-demogrphic Characteristics of the Study Area}

The study on the level of education says that $38 \%$ of the respondents have no primary education and about $6 \%$ have higher education those crossed the secondary level. 19\% of the respondents ended their study at class five or still going for primary education of class five, $15 \%$ have junior level education who ended their education at class eight, $12 \%$ passed secondary education and achieved secondary school certificate of class ten but ended their formal education. The study of the households including different education levels are shown in figure as-

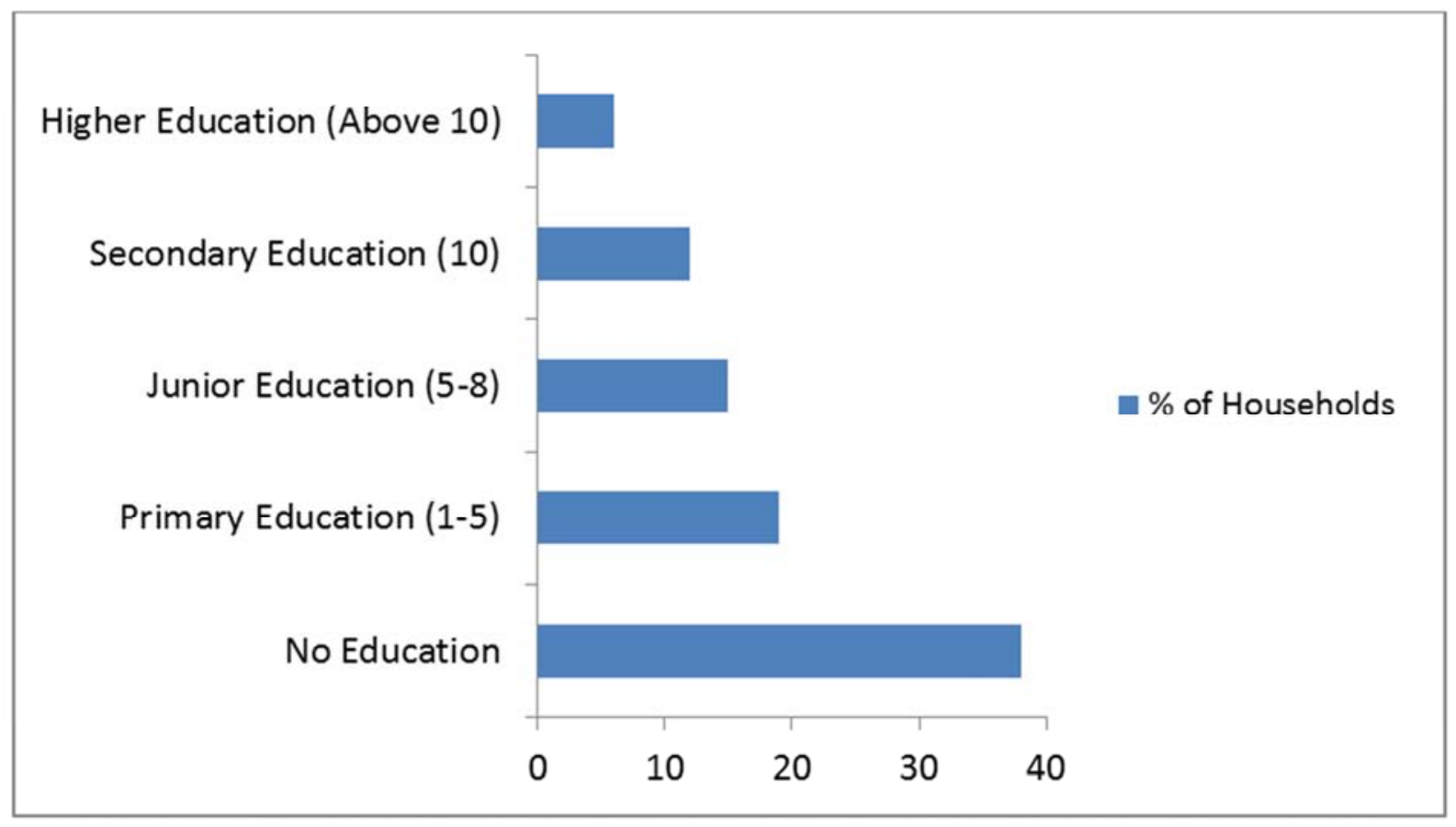

Figure 2. Level of education of the surveyed area.

The household size falls within the range of $100 \mathrm{~m}^{2}$ to 0.005 ha with an average of 0.002 ha. The total homestead area surveyed was 0.194 ha from a total of 100 sampled household.

Table 1. Number and area of the household surveyed.

\begin{tabular}{ll}
\hline & Char Baladoba \\
\hline No of household surveyed & 100 \\
Total homestead area (ha) surveyed & 0.194 \\
Average homestead area (ha) & 0.002 \\
\hline
\end{tabular}

Respondents having homestead size between 0.001 to 0.003 ha have been considered small household. Respondents having homestead size between 0.003 to 0.005 ha have been considered medium household and having homestead size more than 0.005 ha have been considered large home gardens. In the surveyed area, $68 \%$ of the total homesteads were small, $24 \%$ were medium and $8 \%$ were large households. The field data show that; none of the beneficiaries used brick for the walls of their houses. About 34 had the houses made of bamboo. Among others 29 had the houses made of materials like straw or long grass, 16 had mud houses and 19 had the houses made of tin (silvery-white metal). 


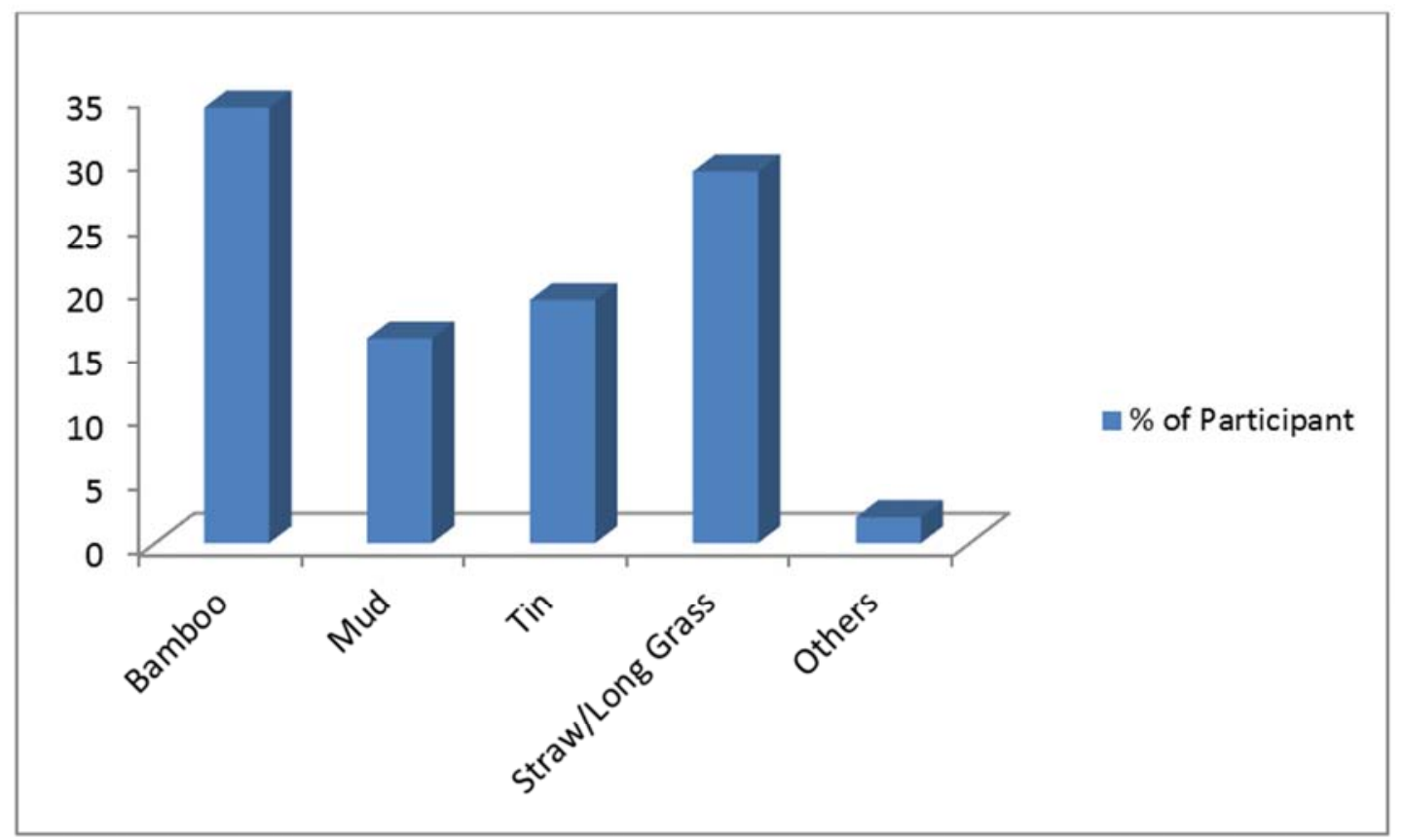

Figure 3. Housing Materials used by the participants.

In the present study, $41 \%$ respondents answered that they were agriculture labor on the basis of daily wage, $26 \%$ said, they worked in fishing; $16 \%$ are day laborer who worked other than agricultural activities on daily basis, $9 \%$ replied that they were house maid and $2 \%$ worked nothing and only $6 \%$ talked about doing business who were mainly involved in grocery in the nearby bazar.

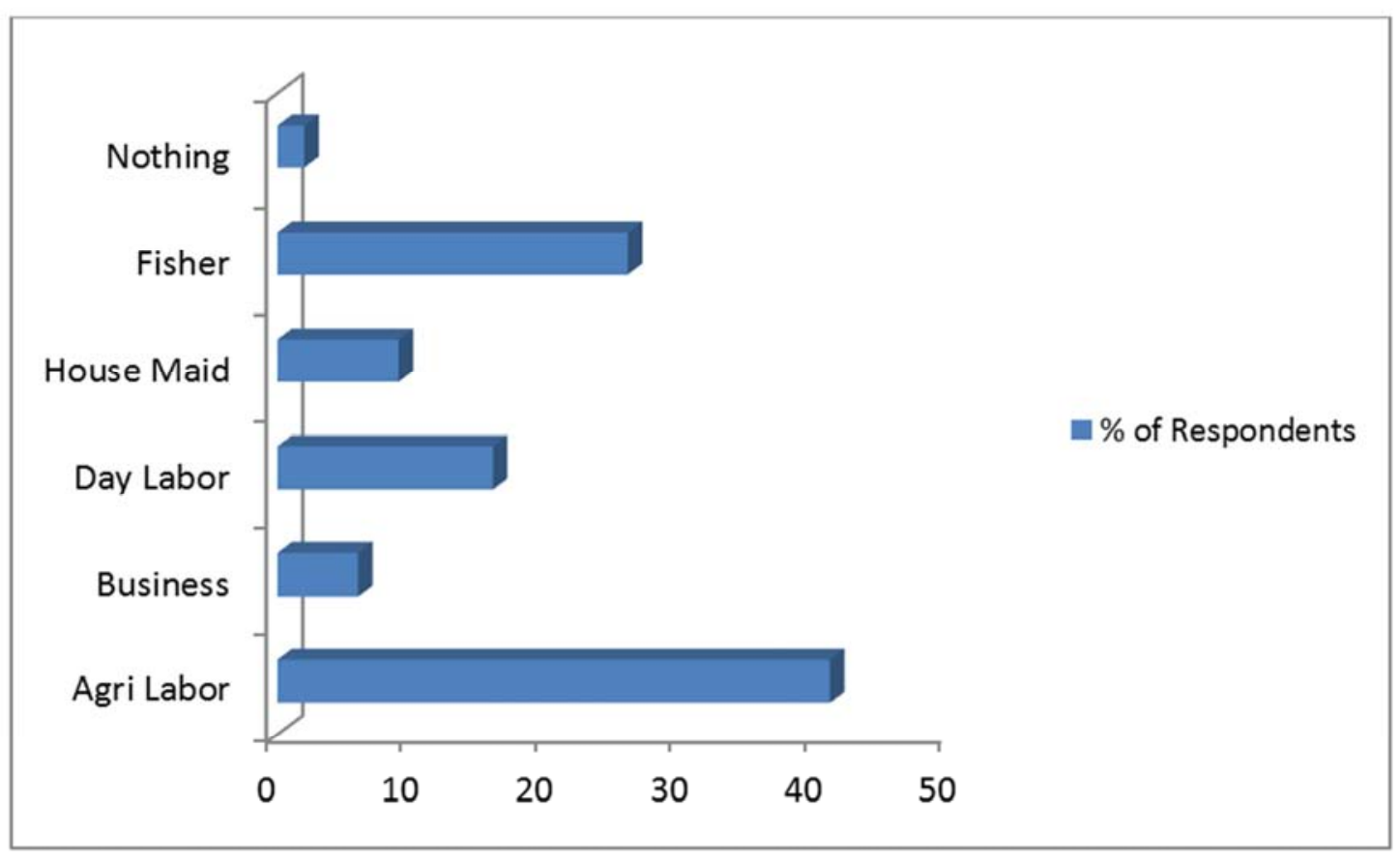

Figure 4. Employment Status of The Respondents.

Most of the people said that the flood in this area is mainly rainfall flood induced river flood. Other than that here flash flood occurs irregularly. 


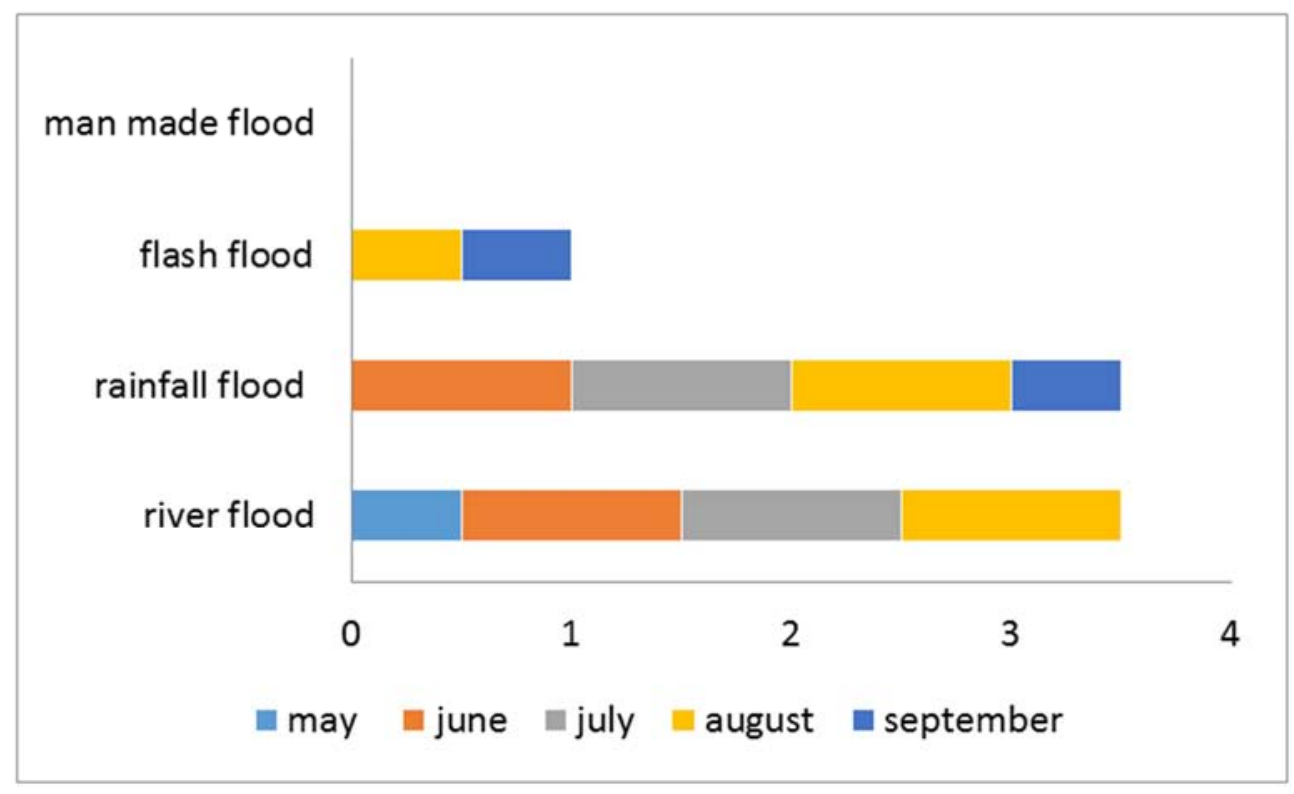

Figure 5. Seasonal flood calendar of the study area with relevant months.

\subsection{Responsibility Taken by Women to Prepare for Flood}

Flood is a common natural phenomena in this village. Every year the people of this area are affected by flood and most of the times flood is either riverine or monsoon. In flood preparedness period the vital role is played by women in the family. At family level women play a central role in disaster preparedness. In view of probable difficulties of disaster they take preparation for processing and preserving of dry food like puffed rice, chira, dry vegetables and dry fishes etc. Dry firewood for cooking during flood is collected by women before flood occurs. Repair of the houses and make the house elevated are executed by both male and female for incoming/future flood. Making matcha (bamboo decorated elevated place) for preserving of food or other useful materials for saving livestock and for themselves during flood and this is regularly done by the women in the charland families.
Plantation of trees is performed by both male and female members but most of the times female members are taking care of these. Shrubs like banana and dhol kolmi (a kind of shrub having many branches and leaves) are planted by women for reducing soil erosion around their houses and which are used as fence during flood and as fuel after flood water goes away. Preserving food for livestock, making portable stove for cooking during flood, preserving of diversified vegetable seed and pure drinking water etc. are performed by women.

Women in the char land save some money so that it can be used during flood and post flood but the amount is very little. Some women said that they do not have enough money to buy their regular foods and that's why they are unable to save money for future.

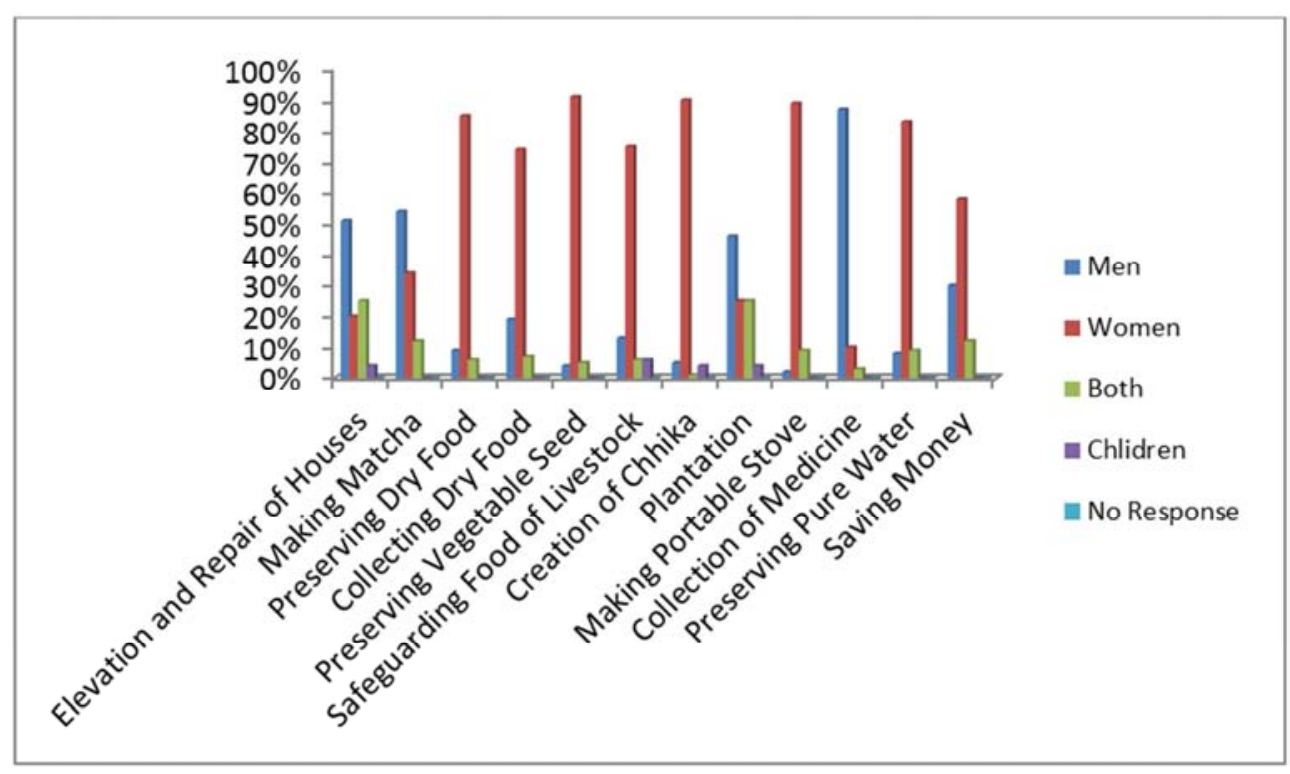

Figure 6. Pre flood activities of community people in Beladoba Char land (\%). 
According to the survey, $85 \%$ respondent said that mainly women perform the food processing and preserving activities in family level where as only $9 \%$ respondent said that male member perform that activities and $6 \%$ respondent said that female and male both participate in those activities. In the case of collecting dry fire wood before flood, $74 \%$ respondent said that it is mainly carried out by female and $19 \%$ respondent said that it is carried out by male member, $5 \%$ replied about both male and female and $2 \%$ mentioned about children. $91 \%$ respondents said that preservation of diversified vegetable seeds generally done by female, $4 \%$ respondents said that this work is done by male and 5\% respondents said that both female and male contribute in those activities. 75\% respondents said that safeguarding the food of livestock mainly accomplished by female, $13 \%$ respondents highlighted about male, $6 \%$ respondents said that both female and male perform that job and $6 \%$ respondents have no idea. Creation of chhika (jute made hanger from ceiling or wall) mainly performed by female to keep hanging utensils above the floor during flood. In the study area $90 \%$ respondent mentioned about female role in chhika creation. Portable stove or mobile Chula mostly made by female, $89 \%$ respondent said that. Preserving pure water mainly performed by female according to $83 \%$ respondent. Female member of the family generally save money from income to face the critical situations during or after the disaster.

\subsection{Organizational Response in Information Dissemination in Warning Phase}

In the char land, formally no organization is found to be involved in forecasting system. People are mainly warned from indigenous knowledge and electronic device such as radio and mobile. Very little numbers of audio visual medium (television) run by solar panel are found here. Some get warning from the personnels of different NGO'S work in charland which occurs in a very informal way. They inform other family members and other people by using mobile or direct conversation. After hearing warning they inform other members of the community, their relatives, communicate with stakeholder. According to the survey $37 \%$ people get warning by electronic device, $31 \%$ by indigenous knowledge, $19 \%$ get warning from family members, $6 \%$ get warning from the personnels of different NGO'S and other 7\% don't get any information.

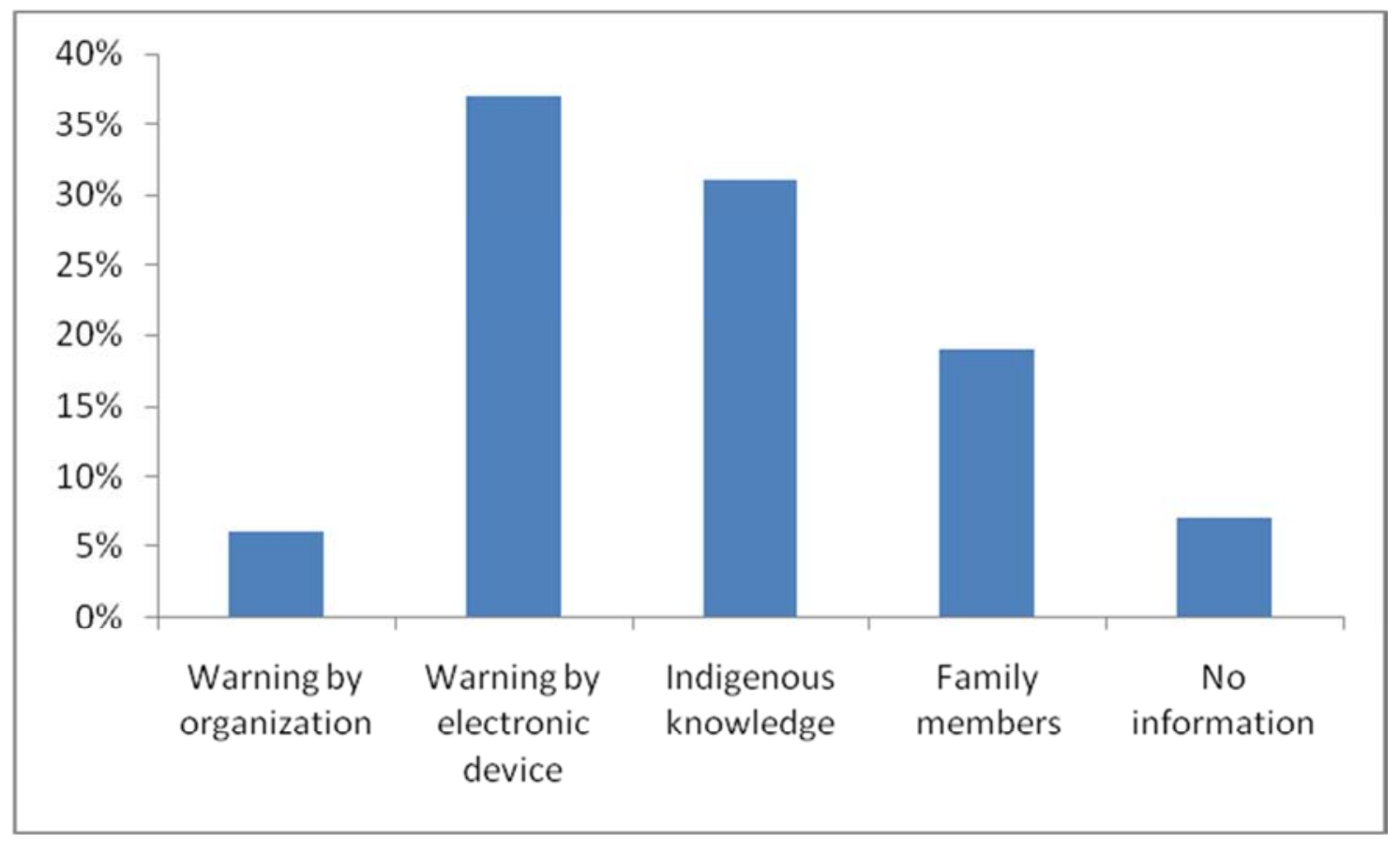

Figure 7. Warning Method.

In the studied area, $53 \%$ people think they get early warning at proper time and other don't think so. $67 \%$ people have no knowledge about shelter place, only 33\% know about that because there is insufficient shelter house there. Some people said that they had heard about shelter but even hadn't seen it.
Most of the families do not go to shelter during flood. They try to make the bed elevated keeping one bed on another and live there. Very few people go to shelter before flood. Only one primary school is used for shelter house purposes. 


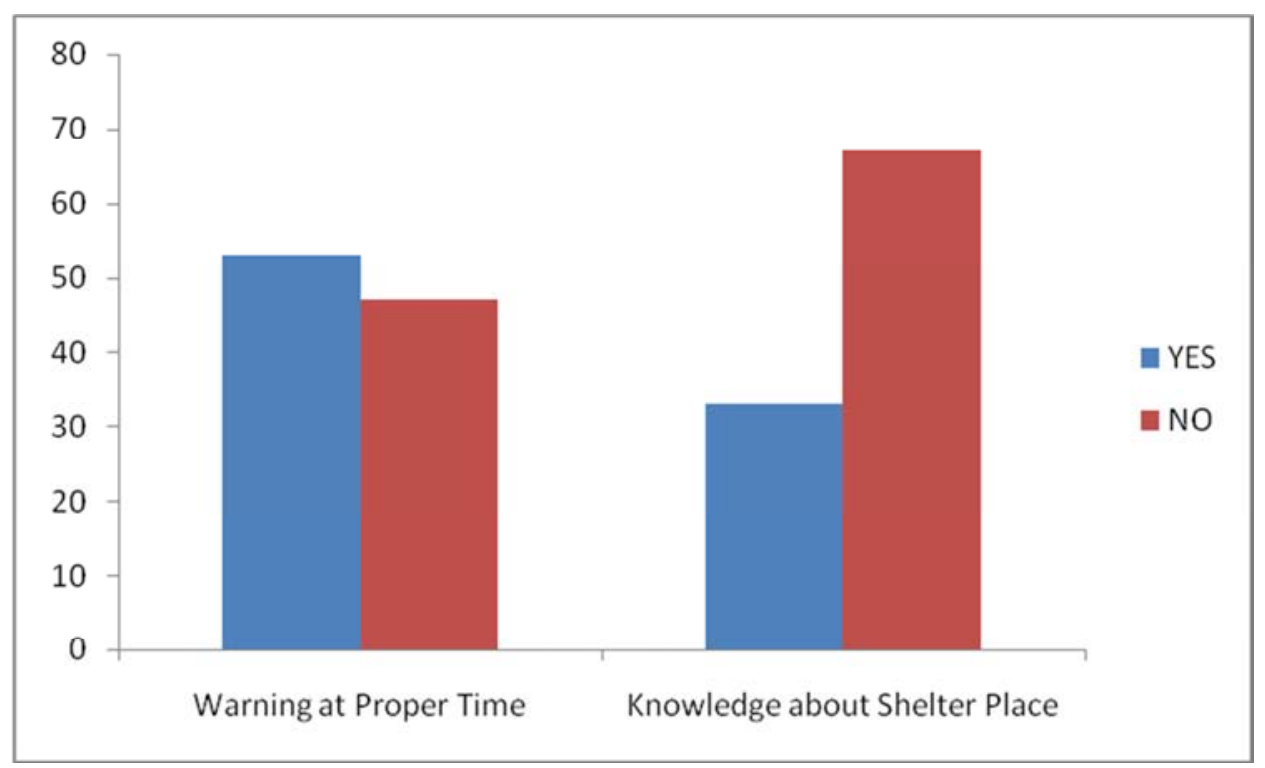

Figure 8. Warning and Shelter.

Whenever they are unable to stay at their houses, they migrate to nearby elevated places leaving all the resources but they don't go to the shelter place. So after migration to the new places they are starting a new phase of life.

\subsection{During Flood Activities}

When flood occurs in this area during June to September, the sufferings of the affected people knows no bound. The entire agricultural land $(100 \%)$ is submerged under water. Standing crops are damaged. Also, the homestead gardens of most of the houses are inundated. So, most of the people starve for 2 or 3 or several days and thus food insecurity is caused followed by high malnutrition. Due to high inundation communication system fails, settlement damages, loss of some of their livestock occurs, sanitation system losses, lack of pure drinking water several water borne diseases arise such as diarrhea, viral infection, fever, malaria and other infectious diseases. Many of the houses are in high char basin and flood water hardly affects them. The families who live in low basin areas save their livestock by building matcha. The families who go to shelter take their livestock, cloths or dry foods. They keep their wooden furniture tie with deep bamboo pole so that these do not float away.

Women play a vital role in during flood by taking care of the health of the old people and children, collection of relief provided by governmental and different nongovernmental organizations, looking after livestock, fetching potable water etc. $70 \%$ women take care of health during flood including nutrition and cleanliness. $62 \%$ of the women play role in keeping family dignity. Livestock are taken care by the $70 \%$ of the women and $85 \%$ women are involved with fetching potable water.

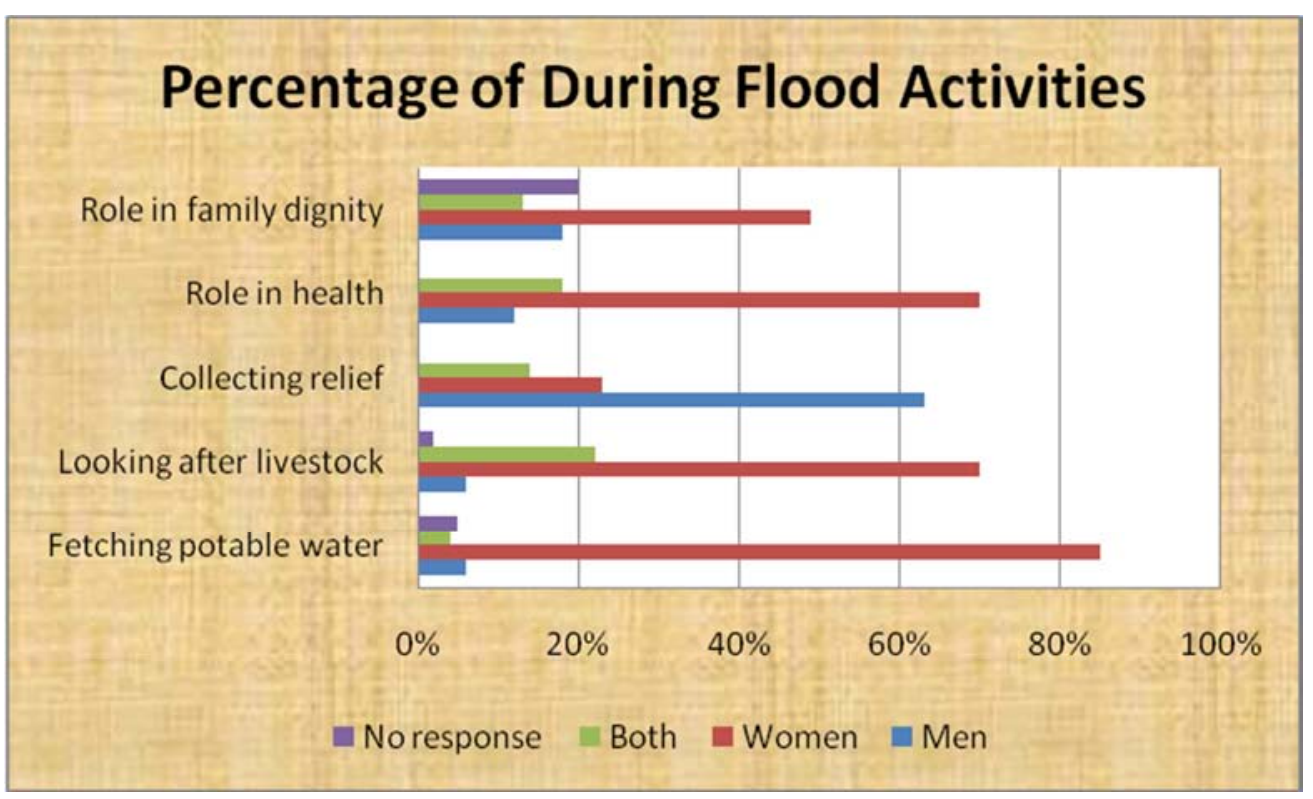

Figure 9. \% of duing flood activities. 
Very few medical services are seen in the locality. Children, disable persons, old persons and women suffer in different diseases and thus vulnerability increases. As there is only one primary school and it is used as shelter house during flood, educational activities are greatly hampered. At this time women play a key role to support their families by ensuring nutrition health as they preserve some dry food, fish and vegetable for flooding season, looking after livestock, taking care of their children and old persons of their family. People informed that there is only two tube wells installed in the high area of the village, so women have to go to a long distance from their houses for collecting pure drinking water. Women preserve their daily necessary things in shhika (a material made of jute fiber to keep things dry in elevated area) on matcha (a high space from ground). If they go to shelter or their relative's house in other area women take the necessary things with them.

\subsection{Women Participation in Post Flood Activities}

After flood, the people who migrate to other areas or take shelter in shelter houses, come back to their home with all their family members. Then they give full attention in reconstruction works such as house repairing, tree planting, homestead gardening, raising yard etc. Some of the families change their living place because of destruction of previous houses due to full inundation by river water or sometimes houses go under river bed. Main earners of the some of the families stay away from their female members and go to other places such as to Dhaka, Comilla or other cities for income issue and women have to manage their families anyhow. In this time they seek help from community people. Most of the owners of relief card of this area are women. So, women collect relief goods such as rice, dull, oil, sanitary napkin, sugar etc. from government and also from NGO's.

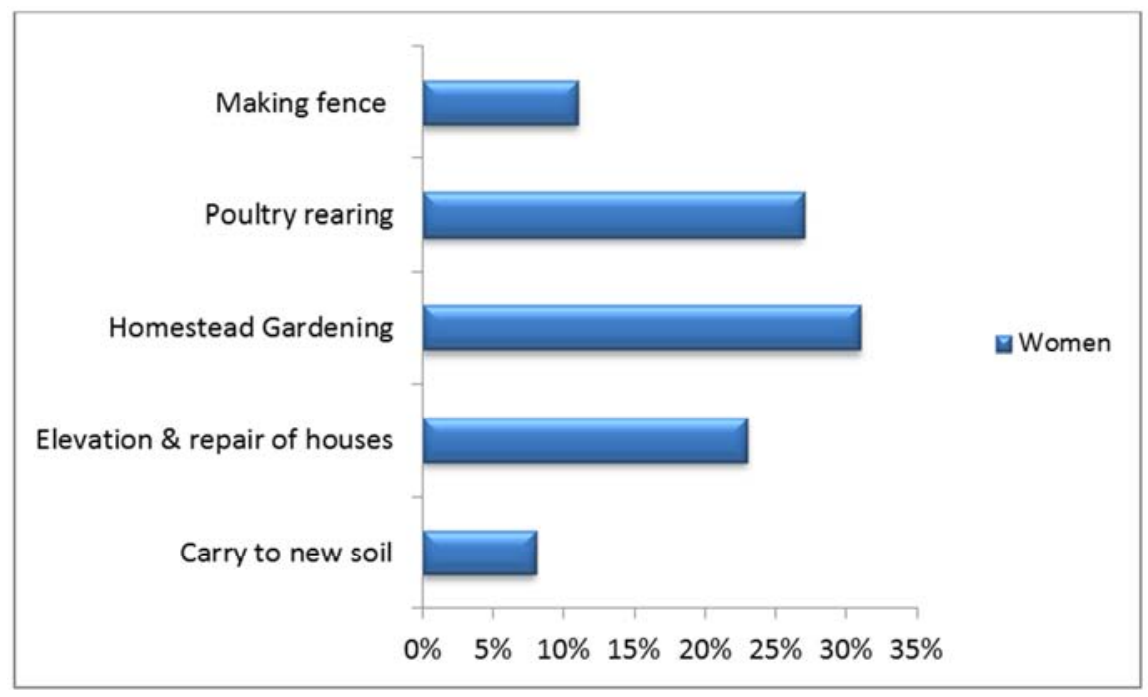

Figure 10. Women participation in post flood activities.

After flood women play very important role keeping pace with men. Carry to new soil are done by $8 \%$ of the women, $23 \%$ women are engaged with elevation \& repair of houses, $31 \%$ women perform in homestead gardening, $27 \%$ in poultry rearing and $11 \%$ in making fence after flood.

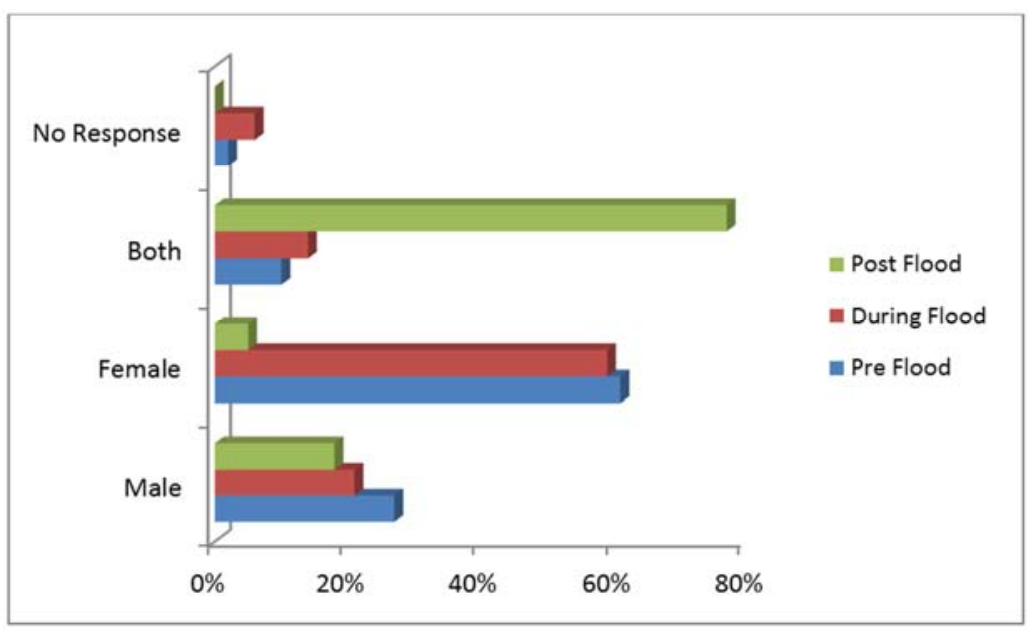

Figure 11. Activities of people in different period of flood. 
The figure shows that among the respondents, $27 \%$ works are prepared by male members, $61 \%$ by female, $10 \%$ are performed by both male and female and no response gathered by rest $2 \%$. During flood period, $21 \%$ are done male, $59 \%$ by female members, $14 \%$ by both and others gave no response. In post flood period, $18 \%$ works are executed by male, $5 \%$ by only female, $77 \%$ by both male and female.

So, this is evident that most of the activities in pre flood, during flood and post flood are accomplished by women. In these three phases majority of the activities are done by women in the family.

\subsection{Social Status of Women}

At south baladoba char in begumganj union in kurigram district in rangpur division, most of the women are illiterate, a few have fundamental education or primary education. A negligible percentage of women have arabic knowledge and religious education. After all most of the women are under educated.

Most of the families in the charland are headed by the male such as father, husband, brother, son etc, here women headed family is rare. In very few cases women are head if they are widowed. In past, male dominated women in every sphere of life. But now, the situation has somewhat changed such as male has given importance to women to some extent. $35 \%$ of the respondents said that at present few decisions are taken by both male and female but it is also in a minor scale. $65 \%$ said that decisions are taken by men without asking female members. Main earner of most of the families is the senior male member of the family. In some cases women also help to earn capital for their family.

\subsection{Coping and Adaptation Mechanism}

People in the char Baladoba, through many generations of experience, developed coping mechanisms for the annual floods. However the significantly increased frequency, intensity and duration of floods disaster over the last ten to fifteen years, have for many families stretched these coping mechanisms to their limit and beyond. This changing disaster perspective, when set amongst the continuing changeover from Struggle and insecurity reveals a picture of many communities being in a considerable state of flux and uncertainty. It is useful therefore, when considering the impact of flooding to distinguish between short-term coping strategies and longer-term adaptive strategies in Table 2:

Table 2. Indigenous coping and adaptive strategies of the locality.

\begin{tabular}{ll}
\hline Coping strategies & Adaptive strategies \\
\hline $\begin{array}{l}\text { Short-term response to a specific shock (e.g. flood, displacement, making } \\
\text { fence, carry to new soil). }\end{array}$ & Long-term behavioral changes. \\
Temporary changes in lifestyle requiring innovative adoption, & Adopting new income generating skills, Changing pattern of cultivation, \\
New/different ways of surviving under stress. & Changes in gender relations as a result of new earning. \\
\hline
\end{tabular}

There has been almost abandonment of traditional variety wet season rice production and finding no other choice a shift to a still established pattern of dry season rice production in the char when two repeated floods occur. The findings the impact of the flooding extends well beyond the period of flood itself and in many senses it is this post-flood impact that has the greater impact on the lives of women and girls as a whole. One of the main coping strategies is sending family members to seek migrant work. The main impact is consequently on the women and girls that remain at home, both in terms of substantially increased workloads, in significantly increased worry levels and potentially in these worries being realized.

There is plenty of significant concern in preparedness terms for the pre-flood and during-flood period. In the char putting aside the issue of rice shortage, it is the lack of safe boats, poor environmental health conditions and poor communication that were most immediately noticeable during the research shown in Table 3:

Table 3. Role played and poor access of Women in the society.

\begin{tabular}{|c|c|c|}
\hline Poor environmental health & Lack of safe boats & Poor communication \& information \\
\hline a) Women role as family health carer & $\begin{array}{l}\text { a) Emergency evacuation, especially for households } \\
\text { without adult males }\end{array}$ & a) Women have less access to information sources \\
\hline b) Women role in environmental hygiene & b) Women's reduced movement & $\begin{array}{l}\text { b) Information communication is often at } \\
\text { inappropriate times for women }\end{array}$ \\
\hline c) Women role as water managers & $\begin{array}{l}\text { c) Women's immense fears for male members out } \\
\text { fishing }\end{array}$ & $\begin{array}{l}\text { c) Message is often formulated without involvement of } \\
\text { women }\end{array}$ \\
\hline
\end{tabular}

\subsection{Poverty Induced Social Crisis "Robbery"}

Most of the male members of this region are day laborer or farmers. During flood they loss their employment opportunities and thus Social crisis and social vulnerability increases. People of the community are very poor and this poverty induces and instigates robbery. Some people are engaged in robbery when there is no food or capital in the flood period and immediately after flood period and these robbers grab the assets of the people. 47 years old Shirin akter said"Robbers come covering their face by gamcha (a cloth used to dry up and rub out wetness of body) and grab our wealth. The come and go very quickly. The robbers are very well known to us, they are kith and kin of ours. Most of the times they come bearing Ramda(a thick local chewing and 
cutting equipment made by iron) or long bamboo stick, they make us fear but don't harm us."

\section{Conclusion}

The role of the participation of women in pre flood, during flood and post flood activities cannot be seen in an insignificant scale. From the study in char Baladoba we got a scenario of whole Bangladesh. The scenario tells us the important function of women in different converse situations, how they cope with the reverse environments and what initiatives they take as adaptation.

\section{References}

[1] Nizamuddin, K. (ed.) 2001; Disaster in Bangladesh: Selected Readings, Disaster Research Training and Management Center, Department of Geography and Environment, University of Dhaka.

[2] CCC (2008). Climate Change, Gender and Vulnerable Groups in Bangladesh. BASTOB and Centre for Global Change (CGC). Climate Change Cell (CCC), DoE, MoEF; Component 4b, CDMP, MoFDM. Dhaka.

[3] Kapoor, A. (2011). Engendering the Climate for Change: Policies and practices for genderjust adaptation, Alternative Futures and Heinrich BÖll Foundation (HBF).

[4] Parikh, J. (2011). Forward statement for the publication, Engendering the Climate for Change: Policies and practices for gender-just adaptation by Aditi Kapoor, Alternative Futures and Heinrich BÖll Foundation (HBF). (p. 6).

[5] Anderson C., 'Gender Matters: Implications for Climate Variability and Climate Change and for Disaster Management in the Pacific Islands', InterCoast Newsletter, 2012.
[6] Dankleman, I. 2010. Gender and Climate Change: An introduction, Earthscan, London.

[7] Ahmed, N. (1995), "Environment, Development and Women: Bangladesh Perspective" in Jahan, Roushan et. al. (eds), (1995), Environment and Development: Gender Perspectives, Dhaka: Women for Women.

[8] Bala, S. K. (2010). Gender Concerns in Interdisciplinary Field Research. Training of Trainers on Interdisciplinary Field Research Methodology. Co-organized by IWFM, BUET and SaciWATERs held at Cox's Bazar, Bangladesh.

[9] Shamim, I. (1995), "Women and Environmental Disasters: Riverine Erosion and Displaced Women as Managers" in Jahan, Roushan et. al. (eds), (1995), Environment and Development: Gender Perspectives, Dhaka: Women for Women.

[10] Jahan, M. (2008) The Impact of Environmental Degradation on Women in Bangladesh: An Overview, Asian Affairs, Vol. 30, No. 2: 5-15, April-June, 2008 CDRB ASIAN AFFAIRS publication.

[11] Alam. K., Naureen, F. and Wahida, B. A., 2008, 'Gender, Climate Change and Human Security in Bangladesh', Action Aid, Dhaka.

[12] Ahmed, A. U., Neelormi, S., Adri. N., Alam, M. S. and Nuruzzaman, K., 2007. Climate Change, Gender and Special Vulnerable Groups in Bangladesh, Final report, BASTOB and Centre for Global Change, Dhaka.

[13] United Nations Development Programme (UNDP). 2009. Resource Guide on Gender and Climate Change.

[14] Nasreen, M. (2008). Impact of Climate Induced Disasters and Adaptation Strategies: A Gender Perspective. Climate Change Impacts and Adaptation Strategies for Bangladesh. ITN Centre and Dept. of Civil Engineering- BUET. (p-256). 